\title{
4 The Hollywood sound paradox: A regress of game music to film music origins
}

Hollywoodsky zvukový paradox: regresia hudby implementovanej $v$ hrách $k$ počiatkom filmovej hudby

DOI: $10.17846 /$ HII.2017.20.247-273

Published by Constantine the Philosopher University in Nitra 2017, No. 20, pp. 247-274

ISSN: $1338-4872$

\section{Martin Flašar}

\section{Abstract:}

Roughly after a half century of the development of game sound and music, computer technology reached such a niveau that it could bring the most fantastic and never heard sounds woven into wholly original and subtle complexes that are fully immersive and ergodic. Instead of this we are experiencing a large romantic orchestra playing in a Hollywood movie style of the 1930s and later. That is the gist of what I am tending to call "the Hollywood sound paradox". It seems there are two clashing tendencies in game music development: one technologically innovative and second stylistically regressive. In this paper I am questioning the process of constructing more and more sophisticated technologies to obtain older and older music genres. Is it possible that game music loses its authenticity originally based on specific media sound? This study provides three short analyses to suggest main stylistic categories of the current game music.

Zhruba po pol storočí od vývoja herného zvuku a hudby v hrách dosiahla výpočtová technika takú úroveň, že dokázala priniest' fantastické a doposial' neexistujúce zvuky. Tie sa vsiakli do úplne 
The Hollywood sound paradox: A regress of game music to film music origins

originálnych a jemných celkov, ktoré považujeme za pohlcujúce a ergodické. Namiesto toho sme svedkami velkého romantického orchestra, ktorý hrá vo filmovom štýle Hollywoodu 1930 rokov (aj neskôr). $V$ tejto štúdii daný jav nazývame „zvukovým paradoxom Hollywoodu". Zdá sa, že existujú dve stretávajúce sa tendencie vo vývoji hudby $v$ hrách: jedna technologicky inovatívna a druhá štylisticky regresívna. $V$ tomto článku dávam do pozornosti proces konštruovania stále viac a viac sofistikovaných technológií za účelom získat' staršie a staršie hudobné žánre. Je možné, že hudba stráca svoju autenticitu pôvodne založenú na konkrétnom zvuku média? Táto štúdia poskytuje tri krátke analýzy pre určenie hlavných štylistických kategórii aktuálnej hudby v hrách.

\section{Keywords:}

sound design, film music, Hollywood sound, game music, software, hardware, authenticity, regression"

zvukový design, filmová hudba, Hollywoodský zvuk, herní hudba, hardware, software, autenticita, regrese".

\section{1 Losing authenticity: from sounds of machine to sounds by machine}

The focus of this essay is the paradox inherent in the last decades of game music development. As we can observe, game music since its early beginnings used to bear distinctive imprints of the medium. Its variety was indisputably limited by both hardware and software conditions. Thus, music and sound displayed or mirrored the possibilities of the used media. In terms of aesthetics this type of music can be perceived as having a high rate 
of authenticity. The mastery of overcoming the new technical limitations was comparable to a mastery of a classical music composer dealing with physical givens of the traditional music instrument. A certain paradox - which had been experienced already in early times of electroacoustic music in Europe - meant the involvement of game coders or programmers in game sound and music composition. It suggests that the first creators of game music were not professionals at all. And it is far from the last paradox of the story.

What we have been witnessing in recent years is a slow but obvious disappearance of authenticity of technologically produced game music. Whereas the first videogames used native sounds produced by rather technically poor chips and in that way represented an authentic product of contemporary hardware (i.e. musical instrument), later, following the growing potential of the hardware, the sounds produced by it became increasingly artificial, virtual and estranged to its hardware source. The first authors and music makers perhaps dreamt about the sounds of the violin, the piano or the human voice, but during the hunt for perfect simulation of traditional musical instruments nobody realized the loss of something 
The Hollywood sound paradox: A regress of game music to film music origins

incomparably more valuable, namely the authenticity of real digital instruments.

Pong (Atari, 1972) as the first video game using sound deserved these sounds rather accidentally by randomly found frequencies on the tone generator as its designer $\mathrm{Al}$ Alcorn refers, speaking of "sounds that were already in the machine" (Kent, 2001: p. 41-42 cited in Collins, 2005).

As Karen Collins points out "most video games music at the time of the early arcade hits [i. e. end 1970s] included one or two-channel tunes either as quick title themes or two to three-second in-game loops" using approximately four-tone schemes (Collins, 2005).

At the time the quality of sound was rather poor due to the use of Programmable Sound Generators (PSGs) based on a simple sound synthesis resulting often in pure waveforms with an almost uncontrolled timbre.

The main attention should be focused on the authors of early video game music. The situation was generally analogous to early electronic music in USA and/or in Europe. It generally followed two patterns: first, the author was technically skilled and they were able to manipulate the technology themselves. In these cases the music was 
technically functional but mostly lacked an artistic value. The second pattern was a collaboration of a technician and an artist. Although it was rather difficult due to the communication barrier between the world of art and the world of technology, it was usually artistically productive.

In the case of early sound video games the first music authors were musically experienced programmers, i. e. music amateurs. Strictly speaking the early sound games did not apply a music composition, rather a sound design (or a dramaturgy of sound). The designers as nonprofessionals were not obliged to compose elaborated scores, especially in a situation when the technology itself would not make it possible. The tendency of keeping the musical structure as simple as possible (due to limitation in computational and/or memory capacity) led designers rather into the realm of pop music using reduced means than into the world of classical (artificial) music with its rich variety of changes in all musical parameters.

The only option how to face the insufficiency of the hardware (or technology generally) was to reduce the music processes and material elements to minimum. Thus, in that point emerged algorithmic composition as a method of economizing on memory space. A set of formal 
The Hollywood sound paradox: A regress of game music to film music origins

rules abstracted from music (described for example by Iannis Xenakis in his Formalized music, 1992) met the newly emerged style of minimalist music. Invented and disseminated by American experimental composers such as Terry Riley, La Monte Young, Philip Glass, Steve Reich or John Adams in the 1960s it found its logical use in computer music. Perhaps the most typical example of the iconic musical software based on these principles was Karsten Obarski's The Ultimate Soundtracker (1987), using sound samples in combination with simple algorithmic operations of repetition (i. e. loop), transposing, etc.

\subsection{Getting hot?}

The video game music development could be also viewed through the lens of Marshall McLuhan's theory of hot and cool media. Following McLuhan's ideas, the music in early video games could be perceived as a cool medium extending hearing in low definition (i. e. providing ears with a small amount of sound data), but on the other hand demanding high player participation (being interactive). To be more concrete, it is the very player's action which 
completes in ergodic way the resulting form of musical structure. From this perspective the simple sound and uncomplicated musical structure must not be understood purely negatively. On contrary it successfully serves as a means of strengthening the player's involvement in the game, their immersion and interaction.

Growing computational capacity of game hardware during the 1980s and 1990s continuously brought a certain warming up (in McLuhan's sense) of game music. The growing possibilities of MIDI polyphony after establishing the standard in 1983, digital sound processing (DSP) or wave table synthesis, represented the fulfillment of musicians' and composers' desires. Out of the blue they became true masters of symphonic music and conductors of their dreams. Now, more than ever, it was obvious that the real goal of game music was to match film music. This was a typical example of a new medium acquiring confidence. On the other hand the tendency of game music authors to match the compositional mastery of film music composers was nothing more than a logical manifestation of a remediation of the previous cultural form. The originally attractive interactivity was later gradually replaced by a certain kind of interpassivity 
The Hollywood sound paradox: A regress of game music to film music origins

(Žižek, 1998). Games to be played were gradually replaced by graphically and aurally opulent games to be watched or perhaps films to be played with.

Thus, the game music development has given rise to a conflict between two following tendencies. The first one could be called a tendency for innovation. New hardware for generating more complex sounds of high resolution emerged, new types of chips, processors, etc. Not to speak of musical software which to a high extent replaced older types of recording studio equipment. These innovations gradually enabled more and more sophisticated sound and music structures. But instead of consistent use of this newly developed technical tools towards yet unheard sounds and new musical forms and structures, game music started to fulfil its second ambition, i. e. to equal the sound developed in Hollywood movies. This moment definitely displayed the hidden complex of game sound trying to reach the level of Hollywood blockbusters. Suddenly, it became clear that for decades game designers were longing for the huge symphonic orchestra sound in a post-Rachmaninoff style. 


\subsection{The Hollywood sound paradox}

As mentioned above, a certain paradox appeared in connection with the development of game music: the more up-to-date a videogame was, the more obsolete and traditional music it used. Thus, today's games in the mainstream production are immensely fascinated by the Hollywood sound idiom crystallized in the film industry starting in the 1930s.

Firstly, let me summarize the Hollywood sound idiom as being described by film music theorists. Jeffrey Richards in his book Imperialism and Music: Britain, 1876-1953 defines the style as follows:

The idiom of classical Hollywood was latenineteenth-century European romanticism, tonal, tuneful, emotional, uplifting, the idiom of Puccini and Richard Strauss. It was imported into Hollywood by two Viennese émigrés, Max Steiner and Erich Wolfgang Korngold. Steiner is the man credited with virtually inventing the Hollywood film score with its atmospheric and 
The Hollywood sound paradox: A regress of game music to film music origins

richly textured music for such films as King Kong (1933), and Korngold is the man who brought prestige to the job of film composer. (Richards, 2001: 281)

As Peter Larsen explains, this late romantic idiom typical for classical Hollywood experienced its golden era in the time period from around 1935 until the 1950s (Larson, 2004: 185). Richards suggests that the second wave of interest in classical Hollywood music surged in the 1970s when a vast amount of Hollywood music was rediscovered, recorded and academically appreciated (Richards, 2001: 281).

So why Hollywood? The answer to this question is definitely far from simple, but it has certainly much to do with the general establishment of the new medium of the video game. The 1970s were the decade when the development of the first sound video games took place. Hollywood film sound could provide an aesthetic model for a successful mass media sound accompaniment that was nevertheless tied up by the unsatisfactory level of sound producing technology inherent to computers of the time. 
Following the logic of progress it is usual that expectations of a new technological and cultural form are higher than those of an existing one. Thus the first goal of game music was to reach the level of film music (with Hollywood in the lead). The second goal would be to overcome Hollywood film music by means of the new medium. At that moment the roles would change: film music would start to imitate and remediate game music because of the higher proportion of innovations in the compositional style provided by this new kind of music. However, that would be a rather simplified concept of linear development.

I would propose to call the real paradox of this process a mirror development of game music. This has nothing to do with Jacques Lacan's stade du miroir (mirror stage) concept proposed at the Fourteenth International Psychoanalytical Congress at Marienbad in 1936 to describe an infant ability to recognize itself as an object in a mirror. My conception is different. Starting in "point zero" of game music, for which one can take the Atari Pong game release of 1972, further development continuously unfolded in contradictory ways, simultaneously forward and backward having point zero as a mirror axis. In other words, the progression identified itself with regression. 


\subsection{Innovation versus regression: from real to virtual sound}

At the starting "point zero" of game sound and music development no remediation was used at all. The approach of game sound designers reflected a tendency to exploit maximally the innovative potential of the available hardware. This state of identification of the instrument (hardware) with its sounds may be termed an "authentic production". What is being produced here is the real sound achieved by the hardware, the sound of the machine. The authenticity of the sound audibly produced by machine has much in common with Andrew McTavish notion of "the meta-space of technological admiration" which is based on the certain type of spectacle performed by technology (Wood, 2014: 138).

Increasingly, the growing capacity of sound hardware enabled composers and sound designers to approach traditional musical instruments by FM synthesis and later by wave table synthesis. Still, the virtual sound of "real" classical instruments represented something very strange and alienated to silicon-based hardware. It was a sound by machine. Thus the more "real" the sound of the 
instruments was, the more virtual it was in fact perceived. The sound of the large symphonic orchestra has nothing in common with the real sound of the machine used for its production. What has been achieved here is a complete loss of the authenticity of game music. In its "mirror development" it reached deep into the history of audiovision, i. e. into the Hollywood sound era of the 1930s.

In this respect the today's phenomena of bitcore, bliphop, 8-bit music, chiptunes, chip music, etc. has become clearer. What became the object of nostalgia was not the old quirky sound style, but rather the authenticity of it referring directly to its source. In short, the new medium of game music cannot satisfactorily be represented by symphonic orchestra as was the film in its golden era, but rather by beeps, clicks and hums. The reason lies in the contemporaneous identity of the medium and the music. Whereas symphonic orchestra was a very common musical ensemble of the 1930s connected mostly with the culture of the bourgeois society (for example with balls or the opera), there is no logic in using it in entertainment at the beginning of the $21^{\text {st }}$ century except in the possibility that it is taken as an allusion to a certain historical period. 
The Hollywood sound paradox: A regress of game music to film music origins

Simultaneously, symphonic music has always functioned as a symbol of the cultural production of a higher social status. Thus, just like the film assumed its social status from the opera by imitating its style, videogame reused the identic strategy of exploiting the film as an already wellestablished cultural form. The historicity of music is indisputably one of the most pressing problems to be solved in the quest for a contemporary authentic game music style.

\subsection{At the crossroads: stylistic solutions of contemporary game music}

As Peter McConnell (Wood, 2014) puts it, there are three basic types of game music, that can coexist even within one game dependently on the game situation and the function they perform: 1. ambient pieces (also described as state music) accompanying a state or condition at which the game has arrived, 2. event-triggered episodes interacting with player actions (isolated sonic gestures having informative function), 3. music as a part of a noninteractive movie (i.e. cut-scene or cinematic). Omitting the event-triggered sonic gestures with strictly semantic 
function, we will follow the two remaining types employing continuous soundtrack. There are typically three stylistic solutions of videogame music nowadays: a. film music remediation, b. 8-bit music nostalgia, c. reasonably progressive music.

4.5.1Challenging Hollywood: Film music remediation

Firstly, composing in a retro style, referring to older cultural forms in order to assume its social status or to imitate a period music style. As Whalen (2007) remarks:

At first glance, video-game music seems quite similar to music in film. Game scores are often arranged by professional, well-respected composers. Soundtracks frequently feature lush, orchestral compositions or collages of pop music, which are often available as standalone albums. Ultimately, whilst the two have a good deal in common, there are clearly unique uses of music in video games [...]

An example of this strategy might be the music in the computer game Mafia: The City of Lost Heaven. This game has won a substantial renown since its release on 
The Hollywood sound paradox: A regress of game music to film music origins

28 August 2002 by a fairly unknown software company Illusion Softworks based in the Czech Republic (later renamed to $2 \mathrm{~K}$ Czech). The game soundtrack used two types of music: popular music of the 1930s (for example Duke Ellington's Caravan) and original symphonic score composed by a little known composer and music arranger Vladimír Šimůnek. His compositions were performed by Bohemia Symphonic Orchestra at Studio B of the National Theatre in Prague, Czech Republic. The orchestra was conducted by Adam Klemens and was produced by Jiři Zobač, an experienced producer of film music (among others the music of Angelo Badalamenti for David Lynch's films).
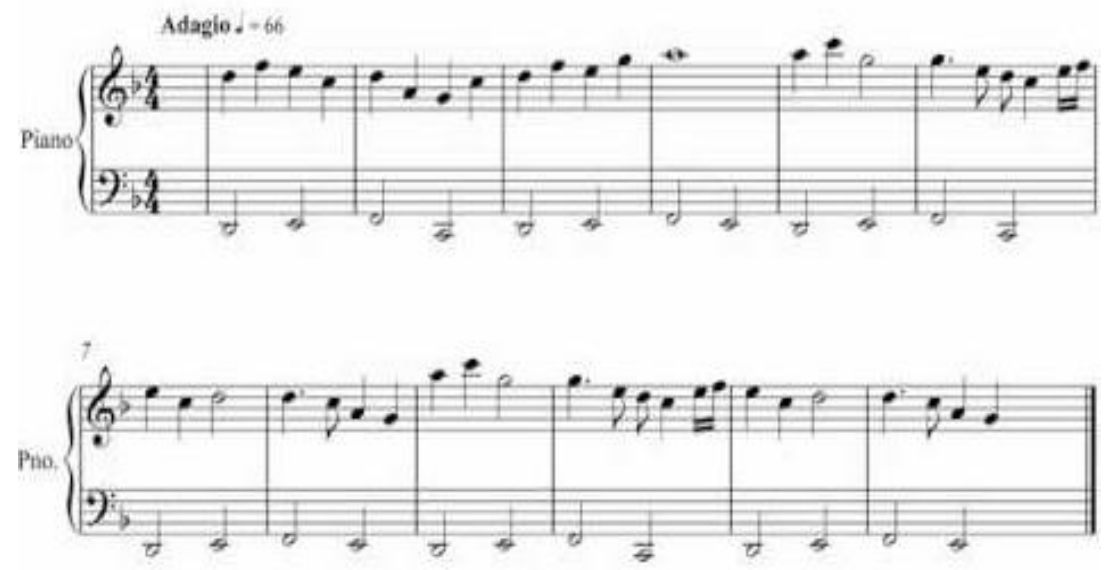
Fig. 1. Mafia, the main theme. Piano transcription by Aleksey Pervushin.

Source: https://i.ytimg.com/vi/A0H01f07nME/hqdefault.jpg

The musical structure is crafted in a style closely resembling the symphonic music of Hollywood blockbusters represented for example by John Williams, James Horner or Hans Zimmer. Voices are emerging gradually in slow tempo (Adagio), expressing the serious, gloomy and bleak atmosphere of the game. Its quite simple diatonic setting in $\mathrm{d}$ minor begins in violin and other strings. We can find here a certain influence of Antonín Dvořák's New World Symphony in the reversed dotted rhythms (bars 6 and 11). This inspiration seems quite logical for a Czech composer striving to render an American spirit (similarly as Dvořák did in his Symphony no. 9).

Fl. I. II.

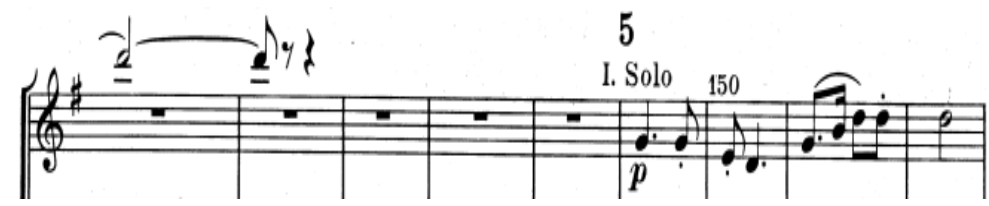

Fig. 2. A. Dvořák: Symphony No. 9, 1st mov., Flute I. Solo, bars 144-152. 
Source: Otakar Šourek (ed.). Antonín Dvořák: Souborné vydání díla, series 3, vol. 9. Prague: SNKLHU, 1955. Plate H 1115.

The style of Šimůnek's piece evokes large Hollywood film scores with their hastily constructed semblance of grandeur using simple techniques of doubling voices, with the melody played alternately by strings or brass instruments and using cymbals at the gradation peaks.

The obvious cinematic quality of the soundtrack is conditioned by the sheer fact that the main theme music is intended to accompany a cut-scene (often also referred to as a "cinematic"). Similarly, it works very well as a part of the game trailer, where it acts as a musical sign of the game.

4.5.2 Longing for a lost authenticity: 8-bit music nostalgia

Secondly, representing the opposite pole, an 8-bit music, which can be perceived today either as an expression of a nostalgia for the "good old times" of primitive hardware- 
limited music, or in a highly puristic and experimental way suggestive of a progressive way of thinking.

In recent years chip music has returned to modern gaming, either in a real full chip music style or using chip sound samples in the music. Among the games using these strategies in their soundtracks are Mega Man Battle Network, Reset Generation, Seiklus, Tetris DS, Sonic Rush, Scott Pilgrim vs. the World: The Game, Super Meat Boy, Bit.Trip Saga, VVVVVV, Super Hexagon, and Fez (Chiptune, 2016).

The most fascinating feature of pocket game consoles such as Gameboy or Nintendo DS was their strict limitation of the sound output. The more restricted the conditions for the music creating were, the greater challenge for programmers or sound designers it represented. The following music example is the Game Over Theme from Tetris DS. Its quasi jazz-rhythm theme is based on a rhythmic pattern $3+3+2$ set in a harmony changing only two chords - B flat major and A flat major.

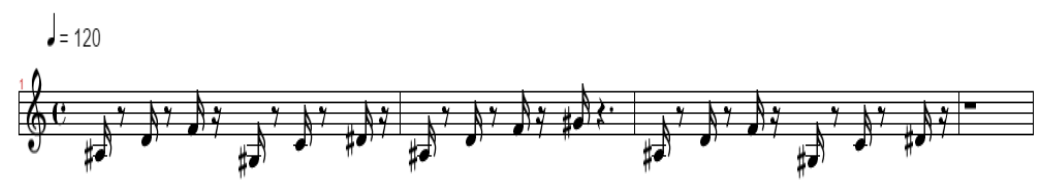

Fig. 3. Tetris DS, Game Over Theme (Nintendo DS). 
The Hollywood sound paradox: A regress of game music to film music origins

Source: $\quad$ https://www.jellynote.com/en/piano-sheetmusic/tetris-ds-nintendo-ds/game-over.

\subsubsection{Reasonably progressive music}

Thirdly, as an option of the golden mean, we can find music that is neither radical, nor nostalgic but indisputably smart. It does not follow the mainstream model of sound and music design and it strives to find its own way forward. This is a characteristic approach of smaller indie productions emerging in the first decades of the twentyfirst century.

The 'indie' label has deployed and foregrounded key features of video games in the first decades of the twenty-first century, including dynamic ambient audio, computer-generated simulations of natural ecologies, and a focus on game mechanics in contrast to visual fidelity or narrative complexity. (D'Errico, 2015: 192)

Here could be mentioned at least the remarkable cooperation of Amanita Design studio (Czech Republic) with a young Czech composer and media artist Tomáš Dvořák (aka Floex). One of the most celebrated products 
of their collaboration was the game Machinarium (released on 16 October 2009). Tomáš Dvořák's soundtrack to the Machinarium adventure game is a set of compositions ranging from ambient to electro-acoustic and classical music frequently using soft sophisticated beats (Dvořák, 2011). The soundtrack to this game represents a typical low-budget approach: one person composing music, performing, mixing and producing it. This goes hand in hand with the smart-organic-eco orientation of Amanita Design's games such as Samorost 2 and 3 (2005, 2016), Botanicula (2012) or Questionaut (2008).

Tomáš Dvořák joined Amanita Design's team for the game Samorost 2, which became his very first game project. The game music was based on loops of one minute maximum. In an interview for the Gamasutra portal Tomáš Dvořák explained:

If you have these short loops, they have to be abstract. If they're too concrete, then it becomes boring or annoying after hearing them ten times." Basically, the composer's aim is to create an atmosphere appropriate to the game situation: "I am always surprised by the process of 'trying to find the right mood for the scene'. [...] There are 
The Hollywood sound paradox: A regress of game music to film music origins

many elements that in the end can be inspiring for the building ofthe right atmosphere. It can be the instrumentation, sound and space design, the melodies and harmonies used, rhythmical structure... (Jeriaska, 2009).

For the music used in the next game Machinarium Tomáš Dvořák got more space than in the previous project. He created more complex and longer pieces that were much closer to autonomous music than to a purely functional one.

\subsection{Making it big. Cui bono?}

The final question of this essay is: what is the purpose of striving for a huge symphonic sound in contemporary game? Somewhat surprisingly, the answer does not lie in the needs of the game itself or perhaps in the style or structure of the music. The problem has to be solved in the social and cultural context of game development. Current trends could be summarized in three main points. Firstly, there is an evident process of institutionalization of game music. Large institutions are beginning to perceive computer games music as a separate area of music and 
begin to study it, evaluate and appreciate. One piece of evidence for this trend are the BAFTA and the MTV prizes for game soundtracks or the Grammy award for interactive play music awarded by the National Academy of Recording Arts and Sciences. There are also emerging separate academic disciplines and game studies research centres, e.g. at Utrecht University or Singapore-MIT GAMBIT Game Lab.

Secondly, there has been an apparent shift of professional film music composers towards PC and video games. Howard Shore, the music composer for The Lord of the Rings trilogy (2001-2003, directed by Peter Jackson) and The Silence of the Lambs (1991, directed by Jonathan Demme) also became the author of the music for the game S.U.N (Webzen, 2007). Another example is Michael Nyman, who collaborated with Peter Greenaway before composing music for the game Enemy Zero (Sega, 1996). Thirdly, it is obvious that quality game music becomes autonomous and like film music it also moves from monitors to concert halls. Recently there have been a number of concerts of computer games music: a European concert of Symphonic Game Music was performed by the Czech National Orchestra; the WDR 
The Hollywood sound paradox: A regress of game music to film music origins

Radio Orchestra has given concerts where game music is a regular part of their dramaturgy. In May 2012, the music by Nobuo Uematsu and Masashi Hamauzu from the games Final Fantasy VI, VII and $X$ were performed in the Stadthalle Wuppertal.

To conclude, we are witnessing a process of game music becoming part of the creative industry. It can be observed that it generally follows patterns introduced by a mass media culture industry with its institutions, producers or competitive mechanisms. Following the tradition of Hollywood film music, game music adopts not only its style but also its business model.

\section{References:}

CHIPTUNE [čipová hudba, alebo 8-bitová hudba ] 2016, January 17. In Wikipedia, The Free Encyclopedia. Retrieved February 25, 2016, from https://en.wikipedia.org/w/index.php?title=Chiptune\&oldid= 700259151.

COLLINS, Karen. 2006. Flat Twos \& the Musical Aesthetic of the Atari VCS. In Popular Musicology Online.

COLLINS, Karen. (2008). Game Sound : An Introduction to the History, Theory and Practice of Video Game Music and Sound Design. MIT Press. 
COLLINS, Karen. (2005, January). From Bits to Hits: Video Games Music Changes its Tune. Film International, 12.

D'ENRICO, Michael (2015, Autumn). Worlds of Sounds : Indie Games, Proceduralism, and the Aesthetics of Emergence. Music, Sound, and the Moving Image, vol. 9, issue 2, p. 192.

DRISCOLL, Kevin. and DIAZ,Joshua .2009. Endless loop: A brief history of chiptunes. In Transformative Works and Cultures, no. 2. Retrieved from http://dx.doi.org/10.3983/twc.2009.0096.

FLAŠAR, Martin. 2012. Hudba a zvuk v počítačových hrách - od filmové $\mathrm{k}$ herní hudbě [Music and sound in computer games - from film to game music]. Opus musicum : hudební revue, Brno: Opus musicum. 44, č.. 4.

JERIASKA. 2009, November 4). Interview: Floex And The Music Of Machinarium. In Gamasutra. Retrieved from http://www.gamasutra.com/view/news/116799/Interview_F loex_And_The_Music_Of_Machinarium.php.

KENT, S. L. 2001. The Ultimate History of Video Games: The story behind the craze that touched our lives and changed the world. California: Random House. p. 41-42 cited in Collins, K. (2005, January). From Bits to Hits: Video Games Music Changes its Tune. Film International, 12. pp. 4-19.

LARSON,Stephen P. 2004. From Bayreuth to Los Angeles: Classical Hollywood Music and Leitmotif 
The Hollywood sound paradox: A regress of game music to film music origins

Technique. In Nasta, D. And Huvelle, D. (Eds.), Le son en perspective: nouvelles recherches. Peter Lang, p. 185.

McLUHAN, Marschall, \& STEAM, Gerald. E. 1968. Hot \& Cool: a primar for the understanding of and a critical symposium with responses. Harmondsworth: Penguin books.

MUNDAY, Rod. 2007. Music in video games. In Sexton, J. (Ed.), Music, Sound and Multimedia: From the Live to the Virtual. Edinburg University Press.

RICHARDS, Jeffrey. 2001. Imperialism and Music: Britain, 1876-1953. Manchester University Press.

ŠIMU゚NEK, Vladimír. 2009. A Biography. (2009, January 15). In Last.fm. Retrieved from http://www.last.fm/music/Vladimír+Šimůnek/+wiki.

WHALEN, Zach. 2004. Play Along - An Approach to Videogame Music. In Game Studies, vol. 4, issue 1. Retrieved 12 July 2012 from www.gamestudies.org.

Whalen, Zach. 2007. Case Study: Film Music vs. Videogame Music: The Case of Silent Hill. In Sexton, J. (ed.). Music, Sound and Multimedia: From the Live to the Virtual. Edinburg University Press.

Wood, Simon. 2014. Video Game Music: High Scores: Making Sense of Music and Video Games. In Harper, G., Doughty, R., \& Eisentraut, J. (Eds.). Sound and music in film and visual media: a critical overview. Bloomsbury Publishing USA. 
Xenakis, Lannis. 1992. Formalized music. Thought and mathematics in composition. Revised edition. Harmonologia Series No. 6, Pendragon Press, Stuyvesant NY.

Žižek, Slavoj. 1998. Cyberspace, or, How to Traverse the Fantasy in the Age of the Retreat of the Big Other. Public Culture, vol. 10, 3, p. 483.

\section{Sources:}

Dvořák, Antonín. 1955. Symphony No. 9. In Šourek, O. (ed.). Antonín Dvořák: Souborné vydání díla. Series 3, vol. 9. Prague: SNKLHU. Plate H 1115.

Dvořák, T. 2011, December 30. Machinarium Soundtrack. In Soundcloud.com. Retrieved from https://soundcloud.com/minorityrecords/sets/machinariumost.

Pervushin, A. Mafia, the main theme. The piano transcription. Retrieved from: https://i.ytimg.com/vi/A0H01f07nME/hqdefault.jpg.

Tetris DS, Game Over Theme (Nintendo DS). Retrieved from: https://www.jellynote.com/en/piano-sheetmusic/tetris-ds-nintendo-ds/game-over.

$==============$
Contact information:

Martin Flasar, Dr

Theory of Interactive Media

Department of Musicology

Masaryk University, Brno, CZ

flasar@phil.muni.cz 